\title{
The Power Sources and Influences of Secondary School Principals in Eastern Ethiopia
}

\author{
Birhanu Sintayehu \\ Haramaya University, Haramaya, Ethiopia \\ https://orcid.org/0000-0002-7935-9264
}

\begin{abstract}
This study aimed to critically examine the power sources and influences of school principals in secondary schools of Eastern Ethiopia. A descriptive survey research design was employed to carry out the study. The participants of the study were 145 teachers, 78 principals, and 41 supervisors who were selected by using stratified and random sampling techniques. The researcher adopted descriptive and inferential statistics to make sound interpretations of data. The results revealed that school principals were mostly used expert, legitimate, and reward sources of power. Likewise, school principals have predominantly exercised a positional basis of power rather than personal power. There was a significant statistical difference in power sources of school principals regarding positions, gender, and service years. The findings also showed that school principals dominantly practiced proactive influencing tactics. Moreover, findings indicated that subordinates carried out school principals' compliance to obtain a prize or avoid punishment by applied reactive influence tactics. The study further discovered that subordinates were inclined to resist school principals' influence. This study suggests secondary principals should rethink how power is managed and deployed to make sound influence over subordinates to assure quality education. Hence, the results of the study may serve as a springboard to improve secondary school leadership and equip novice teachers to bring them a principalship position. Plus, this study may provide a clear picture for policymakers, scholars, and government officials to support and retain principals for long-term school improvement, and it may also a theoretical benefit for future research on the area of study.
\end{abstract}

Keywords: Eastern Ethiopia; influences; leadership; power sources; secondary school; school principals

\section{Introduction}

Power and influences are the most important areas of interest within the field of educational leadership. Leadership is an individual's ability to influence, motivate, and allow others to contribute to an organization's effectiveness and success (Leithwood, Harris \& Hopkins, 2020; Northouse, 2013). To do so, a 
leader uses power as a means of influence to achieve institutional objectives (Alsobaie, 2015). Leadership is an art of utilizing power to influence others (Aslanargun, 2011). Hence, power and leadership are different sides of the same coin. So, power is a leader's capacity to inspire, direct, lead, and motivate others. In brief, power is the ability of a leader to influence subordinates to achieve institutional aims (Nelson \& Quick, 2013). To influence others leader has to be grip power from true sources. People often get confused on interrelated terminologies i.e. leadership-power-influence. In short, Aslanargun (2011) described the relationship between influence, authority, and hierarchy as follows:

Power is the potential of " $A$ " to influence " $B$ " despite resistance. Influence is the result of " $A$ 's" changeable act over " $B$ 's" behavior. An authority is bound to position in an organization based on power and legitimacy. Control is compliance behavior that " $A$ " manages over " $B$ ". It is the success of the influence process. Hierarchy refers to the formal structure of an organization and emphasizes the structure, roles, and division of labor ( $p .7)$.

In brief, power represents the ability to induce someone to do something whereas influence is the exercise of that power. Power is the potential to influence, while the influence is power in action. "Authority is the leader's power to influence others in a specific way, and an important basis for the influence of under formal organization" (Yukl, 2010: p.185). Although power and influence are interrelated in complex ways, they can be separate constructions (Lunenburg, 2012).

Where does this power come from? What gives a person or group influence over others? Power can come from many sources. Based on the concept of leader power, Yukl (2010) pointed out that "the potential influence derived from a leader's position in the organization is the power of the position, and includes legitimate, rewarding information, coercive and ecological, while the characteristic of those in a leadership position is personal power, and includes expert and referent power (p. 185)".

There are two sources of power which namely positional power and personal power (Yuki, 2010). The sources of power that derived from a leader's position are positional power which includes legitimate, rewarding information, coercive and ecological, and while the character of those in a leadership position is personal power, and it includes expert and referent power (Northouse, 2013). Positional power specified that reinforcement and punishment depended on the formal roles of the agent in the organization. Personal power mostly relies on one's charisma, experience, and information based on the characters of the agents (Krause, 2004). Details of each power base and sources are presented in Table 1.

Table 1: Different types of power

\begin{tabular}{ll}
\hline Position power & Personal power \\
\hline Legitimate sources of power & Expert sources of power \\
Information sources of power & Referent sources of power \\
\hline
\end{tabular}


Reward sources of power

Ecological sources of power

Coercive sources of power

Source: Yukl (2010, p. 155)

Pertaining to power sources, an effective and efficient leader mostly used personal power than positional power (Northouse, 2013). However, "it remains important and interacts in a complex way with the personal power to determine the influence of a leader over his followers" (Weinstein, Raczynski \& Peña, 2020: p. 72). Personal sources of power are more closely related to employees' job satisfaction, organizational commitment, and employee job performance than organizational power sources. Furthermore, true leaders are likely to use power subtly and carefully that minimizes differences in status and avoids threats to the target person's self-esteem (Northouse, 2013).

School principals applied different power sources in different circumstances with different situational factors. Most studies of power sources have found that legitimate, rewarding, and coercive powers were incompatible and that correlations with criteria are generally negative or insignificant rather than positive (Goshu \& Woldeamanuel, 2019). Lunenburg (2012) argues that legitimate power could lead to disappointment and resistance if it is not supported by expertise or used excessively. As a result, when a leader frequently relies on legitimacy power, the possible outcome of subordinate is resistance. It has also been found that the powers of experts and referents have a substantial influence on all interactive groups. The formal power only influences subordinates, and that there is little or no influence of the reward and coercive power on external groups in developed organizations (Singh, 2009).

As pertains to school principals' influencing process, tactics, and outcomes of their influence over subordinates, and to be effective as a leader, it is essential to guide followers to comply with given assignments. School principals influence not only subordinates but also students (Dhuey \& Smith, 2018). To influence others, leaders use four very fundamental influencing tactics that may differ in terms of purpose. These are impression management tactics, political tactics, proactive tactics, and reactive (or resistance) tactics (Yukl, 2010). Any tactic can fail if it is not used skillfully and ethically or if it is not appropriate for the purpose and situation of influence.

\subsection{Literature Review}

Sources of Power

Most scholars identified that there are two broad types of power; positional power and personal power (Yukl, 2010). An influence derived from the position of a leader in an organization is positional power that consists of the legitimate power, the power of reward, and the power of coercion, while the characteristics of a person who holds a position in leadership are personal power sources that comprise of information and ecological power (Yukl, 2010). Positional power specified that reinforcement and punishment depended on the formal roles of the agent in an institution. On the other hand, personal power typically relies on one's charisma, experience, and information which is directly related to the 
characters of the agents. Details of each power base and sources are presented as follows.

\section{Legitimate Power}

Most scholars agree on this source of power as the power which derives from the position itself and formal authority overwork. This source of power is awarded by written or verbal contracts from higher officials, and it describes the responsibilities of the manager, and is based on this position sanctioned, authorized, and exalted (Singh, 2009). The amount of legitimate power is determined through the extent of the power the person possesses. So, experienced leaders are inclined to have more power than novice managers and vice versa (Northouse, 2013).

\section{Reward Power}

Reward power is the manager's ability to award or hold back prize like money, privilege, endorsement, or status in itself carries official power (Singh, 2009). Likewise, this power mainly arises from grasping over tangible benefits, and if what a leader presenting as a prize is of no value to an individual, it is likely not to influence behavior (Northouse, 2013).

\section{Coercive Power}

This is the opposite of reward power. This source of power is not only managing prizes but dealing with penalties. So, the coercive power of a leader over his follower is based on the right over the penalty, which differs significantly between different types of organizations (Northouse, 2013). Subordinate mostly believe that he/she can be deprived of something if he/she does not comply (Singh, 2009). When leaders using this power in an institution could not implement sanctions such as arming and shooting, however, it can indirectly bring cancellation of the privilege of workers such as additional payments, a day off (Yukl, 2010). In brief, the manager executes coercive power either by taking away the most important thing from his/her suburbanites or by providing harmful things that may hurt him/her.

\section{Referent Power}

The power of referral arises from the aspiration of someone to please an agent to whom they have strong feelings of adore, respect, and faithfulness (Cogaltay, Yalcin \& Karadag, 2016). These charismatic leaders positively influence others since they are respected and admired by their followers. Likewise, the power of reference allows a leader a shared identity, the personification of the personality, the cult of the hero, the shared culture, or idolatry are some of the sources of power (Singh, 2009). Therefore, the advantage of having a reference power is that it can induce people to do things that may not translate into a tangible reward; the reward comes from the relationship with the charismatic person.

\section{Expert Power}

Many scholars agree that this source of power arises from a person's know-how, knowledge, or talent. Perception of people on an expert as he/she has superior knowledge, skill, and experience on a specific issue than they possess (Aslanargun, 2011). If a problem is fixed enduringly or others train to fix it on their own, the agent's experience is no longer valuable. Most challenging in any 
organization is substituting experienced personal and expert power that he/she possesses. Experience is a basis authority as long as people depend on the agent's pieces of advice and services.

\section{Information power}

This source of power implies figuring out vital information, and then organizing, analyzing, managing, dissemination to others by using his/her position, and communication skill, and network. Information is sources of power in the 21st century, having this power double advantage to the leader to lead a dynamic world (Tran, 2020).

\section{Ecological power}

This power derived from moral, Christian values and Confucian values by the principle of doing good for others as what you would like them to do to you "(Singh, 2009; Trinh, Pham, Cao, Nguyen, Nghiem \& Tran, 2019). It is once able to control physical surroundings, technology, assessing, and scanning the work environment, and sometimes it is known as situational engineering or ecological control.

Investigating the school principals' power sources and influences is a continuing concern within the field of educational administration in Ethiopian secondary schools, yet there is insufficient research that includes their perspective. School principals can play a major role in engaging the school-community and other shareholders to participate in improving school (Mitchell, 2015). Despite the importance of school leadership, there remains a paucity of evidence on the school principals of Ethiopia. The main concern in Ethiopian schools is quantity rather than quality (Semela, 2011), and school leaders face more pressure to increase and maintain enrollment numbers than keeping quality education. Among the countless problems for the deteriorating education quality in Ethiopian secondary is school principals' related problems. The enrolment rate of students from lower primary to higher education is accelerating, but the quality issue is under questing (Goshu \& Woldeamanuel, 2019). Most scholars agreed on fundamental causes for deteriorating education quality is school leadership-related problems.

One of the greatest challenges to the school leadership is a fatalistic picture for school principals. School principals lack the autonomy of administering funds, mobilizing resources, and determining important issues related to teacher recruitment and training (Mitchell, 2015). Utmost challenges for this may be that school principals are not aware of their sources of power and influencing process. In the long Ethiopian education history, there were no formal qualification criteria to lead schools, and school leaders simply elected appointed by government officials (Tekleselassie, 2005). Due to the reasons, the government should take first place for the failure of the quality of schools, school leadership, or principal ship (Goshu \& Woldeamanuel, 2019). Another main challenge faced by many schools is the school principals' improperly excising power and authority over subordinates (Goshu \& Woldeamanuel, 2019). Further, the school management has a strong impact on the job satisfaction of subordinates especially teachers (Cogaltay et al., 2016). Overall, 
these studies highlight the need to examine the school principals' power sources, and the influence of school principals in Eastern Ethiopian secondary schools.

This study aims to fill the following research gaps in the context of Eastern Ethiopia secondary schools. First, there has been no detailed investigation of the mentioned concern, as stated by Mitchell (2012:12: p. 3), "the role of principals in educational leadership particularly proper application of power and influences is a vast field of study, yet little has been written from the perspective of Ethiopia". The impact of educational expansion on the quality of secondary education is understudied, particularly for school leadership. For the past 20 years, the Ethiopian education system has been growing fast, and despite this expansion, however, it created a slew of new problems, such as funding shortages, and a deterioration of quality (Mitchell, 2015). Consequently, concerns for the quality of education under questioned because of rapid expansions of schools Minister of Education (MoE, 2008). Thus, this study provides new insights into power sources and influences of school principals and its implication on education quality.

Finally, to design a framework for the study, it is essential to differentiate leader power sources, influencing tactics, processes, and outcomes. There are three main influencing tactics that any leaders can possess to lead institutions like political, proactive, and reactive tactics. Furthermore, engagement, compliance, and resistance are the three main outcomes of influences (Yukl 2010). The following figure 1 indicates the framework of the study.

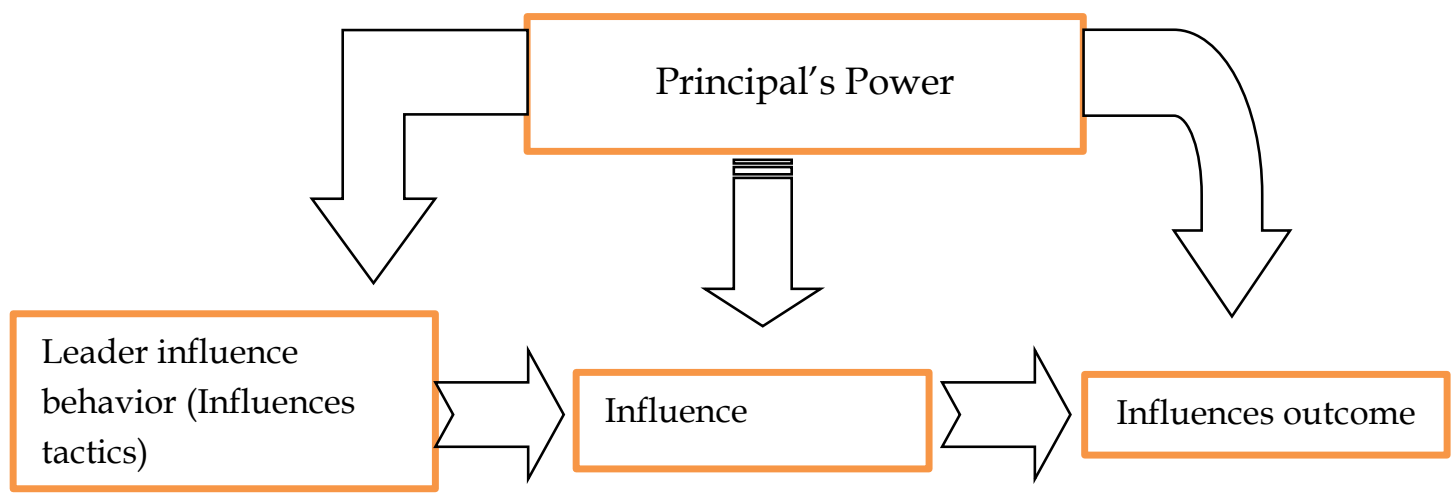

Source: Adapted from Yukl (2010)

Figure 1: Conceptual framework of school principals' power sources, and influencing tactics, process, and outcome

\subsection{Basic Research Questions}

In light of all the above, the aim of this study critically examines the power sources and influences of school principals in secondary schools of Eastern Ethiopia. Hence, this study answers the following basic research questions.

1. What sources of power do school principals mostly use?

2. What kinds of tactics do school principals apply to influence subordinates?

3. Why do subordinates comply for school principals?

4. What outcomes are observed among subordinates for the influences of their school principals? 


\section{Methodology}

Research Design

This study used a descriptive survey research design. The basic ground behind applying this design is to collect data to answer questions about people's opinions, beliefs, attitudes, behaviors, and demographic composition on the current study (Mills \& Gay, 2016). Additionally, this design is appropriate to collect and analyze data with a limited timeline and budget. The researcher also used a quantitative approach for a research strategy that requires collecting numerical data, quantification of collected data, and analysis of data that were selected from school teachers, principals, and supervisors (Creswell, 2012). The participants of this study were made up of teachers, principals, and supervisors who have been serving in different secondary schools in Eastern Ethiopia.

\section{Population and Sample / Study Group/Participants}

This study was conducted in Eastern Ethiopia. It comprised of two zones of Oromia National Regional State (East and West Hararghe), one Administrative City (Dire Dawa), and two districts in Harari National Regional State. The study population $(\mathrm{N}=1,015)$ was composed of secondary school teachers $(n=541)$, principals $(\mathrm{n}=301)$ and supervisors $(\mathrm{n}=173)$. The participating secondary school teachers had a Postgraduate Diploma in Teaching (PGDT) of the 2018/19 academic year batch. Participants were selected via stratified and simple random sampling techniques. The basic reason behind employing the stratified sampling technique was that study groups had different categories (teachers, principals, and supervisors), and it was important to take into account such diverse strata.

To determine sample size from study population, the researchers applied Yamane (1967) $\mathrm{n}=\mathrm{N} \div 1+\mathrm{NE}^{2}$; which $\mathrm{N}=$ total population; $\mathrm{n}=$ sample size, $\mathrm{E}=$ error rate /margin of error (.05) provides a simplified formula to calculate sample sizes and guess: $95 \%$ confidence level $\mathrm{P}=.05$. Thus, sample size determination was calculated as follows:

$$
\begin{aligned}
& N=1015 / 1+\mathrm{NE}^{2} \\
& N=1015 /\left(1+361 * 0.05^{2}\right) \\
& N=1015 / 3.5375 \\
& N=287
\end{aligned}
$$

After determining the sample size from the three groups of the respondents, the researcher used stratified proportional sampling techniques to select respondents from each category.

Table 2: Stratified Sampling Frame

\begin{tabular}{lccl}
\hline Strata & Population size & Sample size & Sampling technique/s \\
\hline Teachers & 541 & 153 & stratified and random \\
Principals & 301 & 85 & stratified and random \\
Supervisors & 173 & 49 & stratified and random \\
Total & 1,015 & 287 & \\
\hline
\end{tabular}


The primary data were gathered via questionnaires (Appendix) from teachers, principals, and supervisors who worked the 2018/19 academic year of secondary schools of Eastern Ethiopia. The first part of the questionnaires was adapted from Hersey and Natemeyer (1979) entitled 'power perception profileperception of others'; it includes 21 pairs of reasons frequently reported when asked why subordinates obey the orders of their school principals. The second part of the questionnaire was prepared by the researcher that aimed to measure school principals' influencing process, tactics, and outcome of the leaders' influence on their subordinates' performance.

The instruments were converted to local languages, such as Afan Oromoo and Amharic to reduce language barriers. To check the reliability of the items, a pilot test was conducted in Bate and Haramaya town secondary schools of Haramaya town. To check the validity of the instrument, area experts were consulted, and their comments were incorporated.

\section{Data Analysis}

The researcher applied descriptive statistics (frequency, percentage, mean score, standard deviation) to describe the nature of the data and the characteristics of the sample in a meaningful manner. Also, inferential statistics (independent ttest and one-way ANOVA) were adopted to compare significant differences that may exist between and within groups of teachers, principals, and supervisors in their perception of principals' power sources about their position, sex, service years, and academic qualification.

\section{Ethical Considerations}

The researcher had given full attention to the moral and ethical issues. Due consideration has been given to ethical concerns of the participants to ensuring and informing consent and developing confidentiality, maintaining anonymity, and other related ethical issues (Cohen, Manion \& Morrison, 2007). The researcher had communicated and assured the participants on their responses will be used only for academic purposes and will remain confidential.

\section{Results}

The demographic data of respondents in this study can be described based on roles and gender. The questionnaire was initially distributed to $(n=153)$ secondary school teachers, $(n=85)$ school principals, and $(n=49)$ supervisors with a total of ( $\mathrm{n}=287)$. Of the total number of the questionnaire distributed to the groups, $264(92 \%)$ i.e. $(n=145)$ teachers, $(n=78)$ principals, and $(n=41)$ supervisors were appropriately filled and returned. Even though the questionnaire retrieval rate is not at $100 \%$, results could not have been affected by this retrieval rate and returned data has statistically sound to precede analysis (Cohen et al. 2007). Based on gender, it was found that about 221 males and 43 females have participated in this study.

The sources of power school principals mostly use

Frequency counts and percentages were used to identify the power sources that school principals mostly applied, as perceived by teachers, principals, and supervisors. The summary of results presented in Table 3. 
Table 3: School Principals' Power Bases and Sources

\begin{tabular}{|c|c|c|c|c|c|c|c|c|c|c|c|}
\hline \multirow{4}{*}{ Power basis } & \multirow{4}{*}{ Sources power } & \multirow{2}{*}{\multicolumn{6}{|c|}{ Categories }} & \multirow{2}{*}{\multicolumn{2}{|c|}{ Total }} & \multirow{2}{*}{\multicolumn{2}{|c|}{$\begin{array}{l}\text { Summary of } \\
\text { power basis }\end{array}$}} \\
\hline & & & & & & & & & & & \\
\hline & & \multicolumn{2}{|c|}{ Teachers } & \multicolumn{2}{|c|}{ Principals } & \multicolumn{2}{|c|}{ Supervisors } & \multirow[b]{2}{*}{$\mathrm{N}$} & \multirow[b]{2}{*}{$\%$} & \multirow[b]{2}{*}{$\mathrm{N}$} & \multirow[b]{2}{*}{$\%$} \\
\hline & & $\mathrm{N}$ & $\%$ & $\mathrm{~N}$ & $\%$ & $\mathrm{~N}$ & $\%$ & & & & \\
\hline \multirow{5}{*}{$\begin{array}{l}\text { Positional } \\
\text { power }\end{array}$} & $\begin{array}{l}\text { Legitimate } \\
\text { Power }\end{array}$ & 16 & 6.1 & 20 & 7.6 & 8 & 3 & 44 & 16.7 & \multirow{5}{*}{155} & \multirow{5}{*}{58.7} \\
\hline & $\begin{array}{l}\text { Information } \\
\text { Power }\end{array}$ & 8 & 3 & 5 & 1.9 & 7 & 2.7 & 20 & 7.6 & & \\
\hline & Reward Power & 14 & 5.3 & 16 & 6.1 & 3 & 1.1 & 33 & 12.4 & & \\
\hline & $\begin{array}{l}\text { Ecological } \\
\text { Power }\end{array}$ & 15 & 5.7 & 11 & 4.2 & 2 & .8 & 28 & 10.6 & & \\
\hline & $\begin{array}{l}\text { Coercive } \\
\text { Power }\end{array}$ & 27 & 10.2 & 2 & .8 & 1 & .4 & 30 & 11.4 & & \\
\hline \multirow{3}{*}{$\begin{array}{l}\text { Personal } \\
\text { power }\end{array}$} & Expert Power & 51 & 19.3 & 19 & 7.2 & 15 & 5.7 & 85 & 32.2 & \multirow{2}{*}{109} & \multirow{2}{*}{41.3} \\
\hline & Referent Power & 14 & 5.3 & 5 & 1.9 & 5 & 1.9 & 24 & 9.1 & & \\
\hline & Total & 145 & 55 & 78 & 29.5 & 41 & 15.5 & 264 & 100 & 264 & 100 \\
\hline
\end{tabular}

Looking at the detailed power sources of school principals reported in Table 3, most participants perceived that school principals apply expert power $(32.2 \%)$, legitimate power $(16.7 \%)$, and reward power $(12.4 \%)$ most of the time. On the other hand, ecological power $(10.6 \%)$, referent power $(9.1 \%)$, and information power $(7.6 \%)$ are sources of power that school principals slightly used to influence their subordinates. The last column in Table 3 summarizes the seven power sources that school principals are executing and further categorizes them into two power bases. Accordingly, school principals are exercising positional power $(58.7 \%)$ and personal power $(41.3 \%)$. To elaborate more about sources of power that school principals mostly possessed, the following figure summarizes in detail.

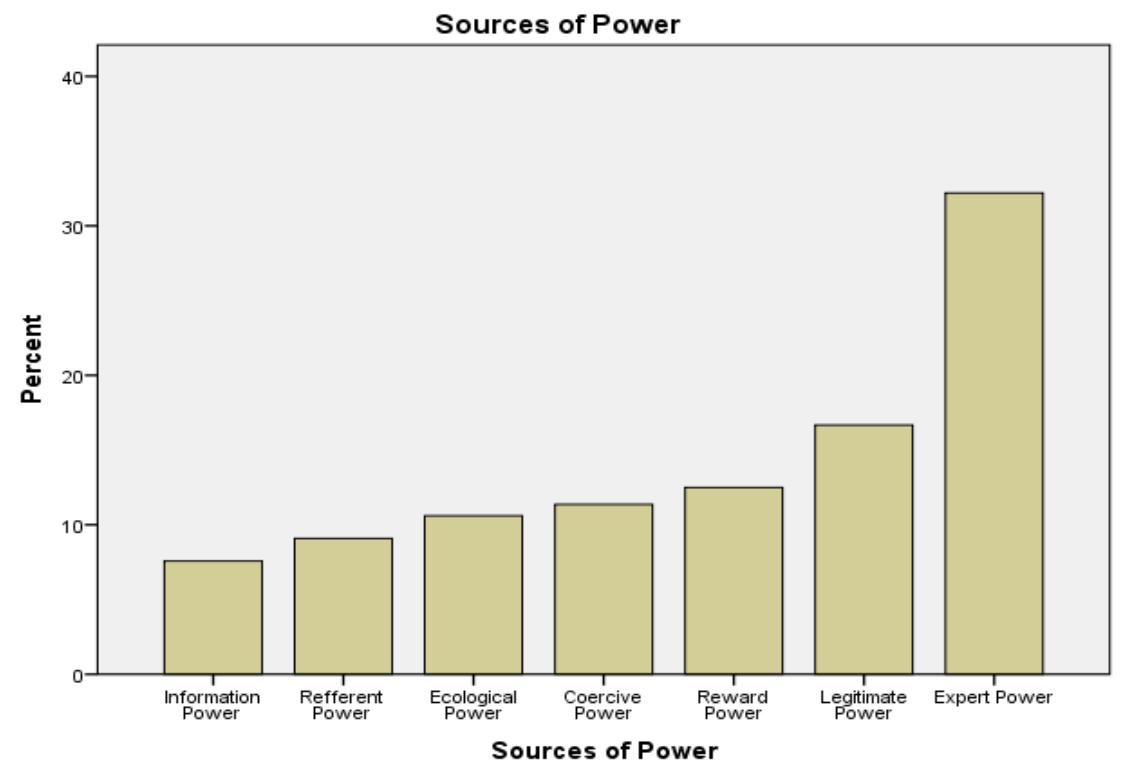

Figure 2: Summary of Power Sources that School Principals' Mostly Used 
The above bar graph described the power sources which school leaders mostly applied, as perceived by teachers, principals, and supervisors. From the graph, it can be seen that expert, legitimate, and reward power are the most utilized power sources by school principals. On the other hand, information, ecological, and referent power sources were reported as principals' least utilized power sources.

Testing Variables on Perceptional Differences in Principals' Sources of Power One-way ANOVA tests were conducted to uncover if there were statistically significant differences amongteachers, supervisors, and principals. The results of these tests are shown in Table 4 below.

Table 4: One-Way ANOVA Test on Perceptual Differences in Principals' Sources of Power by Position

\begin{tabular}{lccclccccr}
\hline \multicolumn{3}{c}{ Descriptive } & \multicolumn{10}{c}{ ANOVA Summary } \\
\hline \multicolumn{1}{c}{ Groups } & N & Mean & SD & \multicolumn{1}{c}{ SV } & SS & Df & MS & F & Sig. \\
\hline Supervisors & 41 & 3.90 & .55 & Between Groups & 3323.71 & 2 & 161.85 & 33.08 & .00 \\
Principals & 78 & 3.73 & .51 & Within Groups & 13111.25 & 260 & 50.24 & & \\
Teachers & 145 & 3.15 & .73 & Total & 16434.96 & 263 & & & \\
\hline \multicolumn{1}{c}{ Total } & 264 & 3.47 & .72 & & & & & & \\
\hline
\end{tabular}

As Table 4 shows, there was a significant statistical difference in the perception of principals sources of power between the three groups: $F(2,263)=33.08$, $p<0.001$. Despite the statistically significant results, the real difference in mean scores between groups was quite slight (Group 1: $M=3.90$, Group 2: $M=3.73$ and Group 3: $M=3.15$ ). To find out exactly where the differences between the groups occurred, post hoc comparisons was applied by using the Tukey HSD test indicated that the mean score for group $2(M=3.73, S D=0.51)$ was significantly different from that of group $3(M=3.15, S D=0.73)$. Group $1(M=$ $3.90, S D=0.55)$ did not differ significantly from group 2 or 3 . Tukey HSD test which indicated that the mean score for supervisors was significantly higher than that of principals and teachers. This implies that supervisors perceive principals' sources of power differently than teachers and principals.

An independent sample t-test was employed to compare whether there was a statistically significant difference in the sources of power of school principals between male and female participants. The results are presented in Table 5.

Table 5: Gender Difference in Sources of Power of School Principals

\begin{tabular}{|c|c|c|c|c|c|c|c|c|c|}
\hline \multirow[b]{2}{*}{ Sex } & \multirow[b]{2}{*}{$\mathrm{N}$} & \multirow[b]{2}{*}{ Mean } & \multirow[b]{2}{*}{ SD } & \multicolumn{6}{|c|}{ t-test for Equality of Mean } \\
\hline & & & & $\mathbf{F}$ & Sig. & $\mathrm{T}$ & Df & Sig. (2-tailed) & MD \\
\hline Male & 221 & 3.53 & .70 & .011 & .916 & 3.89 & 262 & .000 & 4.893 \\
\hline Female & 43 & 3.09 & .71 & & & 3.85 & 58.28 & .000 & 4.893 \\
\hline
\end{tabular}

There was a significant statistical difference in scores for males $(M=3.53, S D=$ $.70)$ and females $(M=3.09, S D=.71) ; t(287)=3.89, p<.001)$. The degree of the differences in the means (mean difference $=-1.03,95 \% C I$ : 2.42 to 7.36 ) was very small $(\eta 2=.005)$. This clearly indicates that there is a difference in perceptions 
between males and females on exercising power sources of school principals. Female principals are more excises personal sources of power than positional than male school principals while leading schools.

One-way between-groups analysis of variance was conducted to compare the mean scores of three groups that were categorized based on academic qualification with sources of power, and One-way among groups ANOVA test results were summarized and presented in Table 6.

Table 6: One-Way ANOVA Test on Perceptual Differences of Power Sources by Academic Qualification

\begin{tabular}{lccclccccc}
\hline \multicolumn{3}{c}{ Descriptive } & \multicolumn{8}{c}{ ANOVA Summary } \\
\hline \multicolumn{1}{c}{ Items } & $\mathbf{N}$ & Mean & SD & \multicolumn{1}{c}{ SV } & SS & df & MS & F & Sig. \\
\hline Diploma & 2 & 3.45 & .13 & Between Groups & 10.403 & 2 & 5.20 & .083 & .92 \\
Degree & 261 & 3.43 & .72 & Within Groups & 16424.55 & 261 & 62.93 & & \\
Master & 1 & 3.72 & - & Total & 16434.96 & 263 & & & \\
\hline \multicolumn{1}{c}{ Total } & 264 & 3.44 & .72 & & \multicolumn{7}{c}{} \\
\hline
\end{tabular}

Table 6 displays the one-way ANOVA results comparing participants' reported perceptions of principals' sources of power by using the mean scores of three groups categorized by participants' academic backgrounds. Participants are categorized into three groups according to their level of academic qualifications (Group 1: Diploma; Group 2: Degree; Group3: Master's). There was no statistically significant difference in perceptions of school principals' power between the three groups: $F(2,263)=.83, p=.92$. Moreover, the descriptive results of each group assured that almost there was no mean difference between groups; G1 $(M=3.45, S D=.13)$; G $2(M=3.43 ., S D=.72)$; G $3(M=3.72, S D=-)$. The result indicates that level of academic qualifications has does not affect exercising different sources of power of school principals.

One-way between-groups ANOVA with posthoc tests administered to see the difference among respondents that grouped according to years of service and perception of principals' use of power, and the test results were summarized and presented in Table 7.

Table 7: One-Way ANOVA Test on Perceptual Differences of Power Sources by Service Years

\begin{tabular}{cccccccccc}
\hline \multicolumn{4}{c}{ Descriptive } & \multicolumn{8}{c}{ ANOVA Summary } \\
\hline Items & N & Mean & SD & SV & SS & Df & MS & F & Sig. \\
\hline$\leq 5$ Years & 174 & 3.34 & .70 & Between Groups & 606.64 & 4 & 151.66 & 2.48 & .04 \\
6- 10 Years & 64 & 3.64 & .74 & Within Groups & 15828.32 & 259 & 61.11 & & \\
11-15 Years & 21 & 3.57 & .52 & Total & 16434.96 & 263 & & & \\
16-20 Years & 3 & 3.21 & .51 & & & & & & \\
$\geq 21$ Years & 2 & 3.77 & .32 & & & & & & \\
\hline Total & 264 & 3.44 & .72 & & & & & \\
\hline
\end{tabular}


Table 7 displays the results of the one-way between-groups analysis of variance were conducted to explore the impact of years of service in study group perception of the use of power by principals. Participants were divided into five groups according to their years of service (Group 1: <5 years; Group 2: 6-10 years; Group 3: 11-15 years, Group 4: 16-20 years; and Group 5 :> 21 years). The result revealed that there was a significant statistical difference in the perception of the use of power scores by principals for the year of service of the five groups: $F(4,259)=2.48, p=0.04$ Despite obtaining statistical significance, the actual difference in mean scores between groups was medium $(3.34,3.64,3.57,3.21$ and 3.77 , respectively). To find out exactly where the differences between the groups occurred, post hoc comparisons was employed using the Tukey HSD test which indicated that the mean score for group $1(M=3.34, S D=0.70)$ was significantly different from that of group $2(M=3.64, S D=0.74)$. Group $3(\mathrm{M}=3.57, S D=$ $0.52)$, group $4(M=3.21, \mathrm{SD}=0.51)$ and group $5(M=3.77, \mathrm{SD}=0.32)$ did not differ significantly from group 1 or 2 .

Influencing tactics, process and outcomes of school principals

The respondents were asked about school principals' influencing tactics, process, and outcome, and they were requested to choose one among the given alternatives. The results are presented in Table 8 .

Table 8: School Principals' Influencing Tactics, Process and Outcome

\begin{tabular}{|c|c|c|c|c|c|c|c|c|c|}
\hline \multirow{2}{*}{$\begin{array}{l}\text { Types of } \\
\text { influences }\end{array}$} & \multirow[t]{2}{*}{ Items } & \multicolumn{6}{|c|}{ Categories } & \multirow{2}{*}{$\begin{array}{c}\text { Total } \\
\quad N \\
\end{array}$} & \multirow{2}{*}{$\begin{array}{l}\% \\
\% \\
\end{array}$} \\
\hline & & $N$ & $\%$ & $N$ & $\%$ & $N$ & $\%$ & & \\
\hline \multirow{5}{*}{$\begin{array}{l}\text { School } \\
\text { Principals' } \\
\text { Influencing } \\
\text { tactics }\end{array}$} & $\begin{array}{l}\text { Reactive influence } \\
\text { tactics }\end{array}$ & 27 & 9.4 & 0 & 0.0 & 1 & .3 & 28 & 9.8 \\
\hline & $\begin{array}{l}\text { Proactive influence } \\
\text { tactics }\end{array}$ & 68 & 23.7 & 42 & 14.6 & 32 & 11.1 & 142 & 49.5 \\
\hline & Political tactics & 36 & 12.5 & 13 & 4.5 & 6 & 2.1 & 55 & 19.2 \\
\hline & $\begin{array}{l}\text { Impression } \\
\text { management tactics }\end{array}$ & 22 & 7.7 & 30 & 10.5 & 10 & 3.5 & 62 & 21.6 \\
\hline & Total & 153 & 53.3 & 85 & 29.6 & 49 & 17.1 & 287 & 100 \\
\hline \multirow{4}{*}{$\begin{array}{l}\text { School } \\
\text { Principals' } \\
\text { Influencing } \\
\text { Processes }\end{array}$} & $\begin{array}{l}\text { Reactive influence } \\
\text { tactics }\end{array}$ & 76 & 26.5 & 31 & 10.8 & 13 & 4.5 & 120 & 41.8 \\
\hline & Internalization & 41 & 14.3 & 42 & 14.6 & 30 & 10.5 & 113 & 39.4 \\
\hline & $\begin{array}{l}\text { Instrumental } \\
\text { compliance }\end{array}$ & 36 & 12.5 & 12 & 4.2 & 6 & 2.1 & 54 & 18.8 \\
\hline & Total & 153 & 53.3 & 85 & 29.6 & 49 & 17.1 & 287 & 100 \\
\hline \multirow{4}{*}{$\begin{array}{l}\text { School } \\
\text { Principals' } \\
\text { Influence } \\
\text { outcomes }\end{array}$} & Commitment & 23 & 8 & 15 & 5.2 & 5 & 1.7 & 43 & 15.0 \\
\hline & Compliance & 44 & 15.3 & 21 & 7.3 & 12 & 4.2 & 77 & 26.8 \\
\hline & Resistance & 86 & 30.0 & 49 & 17.1 & 32 & 11.1 & 167 & 58.2 \\
\hline & Total & 153 & 53.3 & 85 & 29.6 & 49 & 17.1 & 287 & 100 \\
\hline
\end{tabular}

As indicated in Table 8, school principals are influencing their subordinates by using reactive influence tactics $(9.8 \%)$, political tactics $(19.2 \%)$, impression management tactics $(21.6 \%)$, and proactive influence tactics $(49.5 \%)$. These findings clearly indicate that most of the respondents noted their school principals applied influencing tactics, specifically proactive inflecting tactics. 
Pertaining to school principals' influencing processes, principals were liable to rely upon instrumental compliance $(18.8 \%)$, internalization $(39.4 \%)$, and reactive influence tactics $(41.8 \%)$. Therefore, most of the respondents stated that school principals are predominantly using reactive influencing processes for persuading school subordinates.

Relating to the influence outcome of school principals on the job performance and satisfaction of their subordinates, the summary results of the respondents reported that commitment $(15.0 \%)$, compliance $(26.8 \%)$, and resistance $(58.2 \%)$. Thus, statistically, data clearly indicated that subordinates are mostly resisting their school principals' influence. If the subordinates are dissatisfied by their respective leaders it is too hard to bring change and reform in an institution (Brezicha, Ikoma, Park \& LeTendre, 2020).

As seen in the above Table 8 , school principals are mostly applying proactive influencing tactics to influence subordinates. Likewise, reactive influencing tactics are a reason for subordinates complying with principals' requested actions. Furthermore, most of the time subordinates showed resistance towards their school principals' influence.

\section{Discussions}

The major aim of this study was to examine school principals' power sources, and influencing tactics, processes, and outcomes in secondary schools of Eastern Ethiopia. Four research questions guided the study.

The first key finding was that expert, legitimate, and reward powers are the power sources which school principals mostly applied to influence their subordinates. As Aslanargun (2011) argues, expert power is strongly accredited in an organization that leaders and followers trust one another. When school leaders appropriately applied the above-mentioned sources powers, the leader's behaviors could simply be internalized, leading to compliance. Likewise, if subordinates are internally motivated, they no longer need to be controlled as is the case with reward and coercion. Further, Singh (2009) conducted a study on 'Organizational Power in Perspective': results depicted that excessive use of legitimate and expert power, slows down motivation and creativity of workers, while the lack of power delay decision-making. Likewise, Mitchell (2012) suggests the most powerful means of influencing others is having a positive relationship.

Ironically, school principals slightly used referent, information, and ecological power sources to influence their followers. If school principals rarely apply the power of referent, subordinates cannot evoke a sense of trust, loyalty, fulfillment, and responsibility towards subordinates, as well as enthusiasm towards a leader (Aslanargun, 2011). Also, school principals are exercising positional power $(58.7 \%)$ and personal power $(41.3 \%)$. Likewise, principals mostly applied coercive influence of power over the teachers (Özaslan, 2018). School principals are steadiness applying a positional and personal basis of power. However, they are slightly exercising the positional power basis than personal sources of power. This finding directly contradicts the personal sources 
of power is paramount important for employee job satisfaction, organizational commitment, and job performance than positional sources of power (Lunenburg, 2012; Weinstein et al., 2020). Likewise, even though school leaders are expected to apply shared leadership to influence their followers, their level of application is not this much (Goksoy, 2016). Based on the result and discussions, it is possible to conclude that secondary school principals in Eastern Ethiopia mostly practice positional power. In particular from power sources perspectives they are highly exercising expert, legitimate, and reward power.

Another finding was that there was a statistically significant difference amongst teachers, principals, and superiors in their perception of power sources of school principals. The disparity in mean scores between principals and teachers was quite small. In addition to the gender variable, there was a significant difference in scores of males and females, and the degree of the differences in the means was very small. This clearly indicates that gender has a significant effect on male and female principals to apply different sources of power. Regarding to academic qualification, there was no statistically significant mean differences in perception of the power of sources of school principals for the three-level (Diploma, Degree, and Master's) qualifications. Moreover, there was a statistically significant difference in the perception of principals' use of power scores for the five groups' service years. The actual difference occurred in mean scores of service years between ( $\leq 5$ Years) and (6- 10 Years) were a small effect size. Based on the result and discussions it is briefed that there was a significant difference in power sources of school principals concerning positions, gender, and service years; however, there was no statistically significant difference in academic qualification.

The second key finding was that, even though school principals are using four basic influencing tactics namely impression management, political, proactive, and reactive influence tactics; they are predominantly applying proactive influence tactics. A certain situation may dictate the leaders what influencing tactics they should apply based on a given circumstance (Theron, 2020; Yukl, 2010). School administrators ought to recognize and give values to how they are exercising their power and influencing others (Stravakou, Lozgka \& Melissopoulos, 2018). Based on the result and discussions it is concluded that school principals are mostly using proactive influence tactics than the rest types of tactics. Thus, school principals are using reasonable influence and factual evidence to make the request feasible (Aslanargun, 2011).

The third important finding was influencing the processes of school principals are instrumental compliance, internalization, and reactive influence. Most of the respondents, however, reported that subordinates carried out compliance and principals' requested action due to reactive influence, which suggests they obey to obtain a reward or avoid a penalty. Ironically, the result is reversed with stakeholders of the secondary are overloaded with resistance forces, while principals' experiences of change or leadership are more optimistic with fewer resistance forces (Van Wyk, Van der Westhuizen \& Van Vuuren, 2014). School stakeholders resist while principals' experiences of change or leadership are more optimistic with fewer resisting forces 
The fourth major finding was that the influence of the school principals brings three types of influence outcomes on subordinates' performance: commitment, compliance, and resistance. Most of the respondents, however, reported that subordinates mostly resisting their school principals' influence (Twalh, Alsolami, Cheng, \& Islam, 2016). Further, the best way to lead employees as a manager is to become a storyteller meaning that leaders should always focus on creating user-friendly and interactive environments, rather than tense environments, in which the storyteller (manager) always engages and puts the audience at ease (Yan, 2020).

\section{Conclusions}

Based on the prior results and discussions, the researcher drew the following conclusions:

It is possible to conclude that secondary school principals in Eastern Ethiopia are mostly practicing positional power. In particularly from power sources perspectives they are highly exercising an expert, legitimate, and reward power. Thus, it is recommended that school principals should balance both sources of power, and then apply personal sources of power to ensure employee job satisfaction, organizational commitment, and job performance. There was a statistically significant disparity in power sources of school principals concerning positions, gender, and service years; however, there was no statistically significant difference in academic qualification. Also, higher education officials and policymakers at the MoE, Minister of Sciences and Higher Education (MoSHE), Regional Education Bureau, Zonal Education Bureau, and district education offices should take in to account staff seniority, gender, and service years when they assign and appoint principals (Tingle, Corrales, \& Peters, 2019).

Most of the time, an organization does not succeed because attention had not given to how leaders' power is managed and deployed (Twalh et al., 2016). School principals are mostly using proactive tactics than the rest two. Therefore, school principals should create a conducive work environment and positive school culture so that subordinates carry out requested action by recognizing compliance intrinsically, allowing them to maintain a relationship and favor with their leader. Teachers' perceptions of school principals influenced school culture and affected the teacher's work (Britton, 2018). Subordinates are obeyed by the school principals simply to reacting to order and instruction which they have given. Thus, it is possible to conclude subordinates are obeying school principals intended to obtain a tangible reward or avoiding punishment. It is of paramount importance that all school shareholders should friendly work together for the realization of intuitional goals (Kolleck, 2019; Eyal \& Yarm, 2018). Lastly, resistance influence outcome is mainly observed among subordinates for the influences of the power of their school principals. Thus, subordinates are mostly resisting their school principals' influence. Principals then need with teachers to maximize their potential and efficiently utilize their capacity (Tang, Chen, Knippenberg, \&Yu, 2020; Heffernan,2018). School principals suggested motivating, encouraging, and inspiring subordinates to overcome unnecessary resistance and confrontation while managing schools. 


\section{The Implication for Future Research}

The study implies that there are only a few studies carried out in Ethiopia in general and Eastern regions in particular that are related to the power sources and influences of secondary school principals. Thus, based on the results, it is clear that how school principals' power is managed and deployed to make sound influence over subordinates to assure quality education. Also, it is evidence-based that the result of the study serves not only as a means of improving school leadership and teaching but also in rising and maximizing junior staff to shoulder responsibility in administrative areas for the future and to enhance their problem-solving skills. This study would add new knowledge on the power of and sources of influences of secondary school principals. The findings of the study have theoretical, practical, and policy-related benefits for the improvement of secondary school leadership.

However, this study has its own limitations, firstly, due to the resource constraints, the research addresses only some selected secondary schools of eastern Ethiopia. As a result, the research finding may not be generalized for all secondary school principals of Ethiopia. Secondly, since the study secured only quantitative data from the respondents it has methodological limitations too. Future research is needed to gain a more general understanding of the power sources and influences of school principals in the same areas in depth (Yan, 2020).

\section{References}

Alsobaie, M. F. (2015). Power and Authority in Adult Education. Journal of Education and Practice, 6(15), 155-159. https://doi.org/10.2304/power.2010.2.1.63

Aslanargun, E. (2011). The power sources that principals handle in school administration. Eğitim ve İnsani Bilimler Dergisi: Teori ve Uygulama, 2(3), 3-28. Retrieved from https://dergipark.org.tr/tr/download/article-file/210634

Brezicha, K. F., Ikoma, S., Park, H., \& LeTendre, G. K. (2020). The ownership perception gap: Exploring teacher job satisfaction and its relationship to teachers' and principals' perception of decision-making opportunities. International Journal of Leadership in Education, 23(4), 428-456. https://doi.org/10.1080/13603124.2018.1562098

Britton, E. M. (2018). Influence of School Principals on Teachers' Perceptions of School Culture. Doctoral Dissertation, Walden University. Retrieved from https://scholarworks.waldenu.edu/dissertations.https://scholarworks.walden u.edu $/$ cgi/viewcontent.cgi?article $=6448 \&$ context $=$ dissertations

Cogaltay, N., Yalcin, M., \& Karadag, E. (2016). Educational leadership and job satisfaction of teachers: a meta-analysis study on the studies published between 2000 and 2016 in Turkey. Eurasian Journal of Educational Research, 62, 255-282. http://dx.doi.org/ 10.14689/ejer.2016.62.13

Cohen, L., Manion L., \& Morrison K. (2007). Research Methods in Education (6 ${ }^{\text {th }}$ ed.). New York: $\quad$ Routledge. Retrieved from https://www.tandfonline.com/doi/abs/10.1111/j.14678527.2007.00388_4.x

Creswell, J. W. (2012). Education research; planning, conducting, evaluating, quantitative and qualitative research. United states of America, Pearson Education, inc. Retrieved from https://www.amazon.co.uk/Educational-Research-ConductingQuantitative-Qualitative/dp/0134519361 
Dhuey, E., \& Smith, J. (2018). How school principals influence student learning. Empirical Economics, 54(2), 851-882. https://doi.org/10.1007/s00181-017-1259-9

Eyal, O., \& Yarm, M. (2018), Schools in cross-sector alliances: what do schools seek in partnerships?, Educational Administration Quarterly, 54(4), 648-688. https://doi.org/10.1177/0013161x18765268

Goksoy, S. (2016). Analysis of the relationship between shared leadership and distributed leadership. Eurasian Journal of Educational Research, 65, 295-312 http://dx.doi.org/10.14689/ejer.2016.65.17

Goshu, B. S., \& Woldeamanuel, M. M. (2019). Education Quality Challenges in Ethiopian Secondary Schools. Journal of Education, Society and Behavioural Science, 31(2), 115. https://doi.org/10.9734/jesbs/2019/v31i230147

Heffernan, A. (2018). Power and the 'autonomous' principal: Autonomy, teacher development, and school leaders' work. Journal of Educational Administration and History, 50(4), 379-396. https://doi.org/10.1080/00220620.2018.1518318

Hersey, P., \& Natemeyer, W. E. (1979). Power perception profile. Escondido, CA: Center for Leadership Studies.

Krause, D. E. (2004). Influence-based leadership as a determinant of the inclination to innovate and of innovation-related behaviors: An empirical investigation. The leadership quarterly, 15(1), https://doi.org/10.1016/J.LEAQUA.2003.12.006

79-102.

Kolleck, N. (2019). The power of third sector organizations in public education. Journal of Educational Administration, 57(4), 411-425. https://doi.org/10.1108/jea-08-20180142

Leithwood, K., Harris, A., \& Hopkins, D. (2020). Seven strong claims about successful school leadership revisited. School Leadership \& Management, 40(1), 5-22. https://doi.org/10.1080/13632434.2019.1596077

Lunenburg, F. C. (2012). Power and leadership: An influence process. International Journal of Management, Business, and Administration, 15(1), 1-9. Retrieved from https://www.coursehero.com/file/26929224/Power-and-Leadership-AnInfluence-Process-pdf/

Mills, G. E., \& Gay, L. R. (2016). Educational research (11 ${ }^{\text {th }}$ eds.). Upper Saddle River, NJ: Pearson. Retrieved from https://journals.sfu.ca/jalt/index.php/jalt//view/41(Accessed on April May 19, 2019).

Mitchell, R. (2012). Practitioner reflections from a cluster unit in a college of teacher education in northern Ethiopia. MA assignment, University of Leeds, UK. Retrieved from https://www.educ.cam.ac.uk/people/staff/mitchell/

Mitchell, R. (2015). The implications of school improvement and school effectiveness research for primary school principals in Ethiopia. Educational Review, 67(3), 328342. Retrieved from https://www.academia.edu/7108725/The_implications _of_school_improvement_and_school_effectiveness_research_for_primary_scho ol_principals_in_Ethiopia

Minster of Education (MoE). (2008). General Education Quality Improvement Package (GEQIP), Addis Ababa. Retrieved from http://documents1.worldbank.org/curated/en/ 258681468023106655 /pdf/451400PAD0P1061LY10IDA1R20081031311.pdf

Nelson, D. L., \& Quick, J. C. (2013). Organizational behavior: Science, the real world, and you engage learning ( $4^{\text {th }}$ ed.). Boston: Pearson education. Inc. Retrieved from http://go-pdf.online/nelson-and-quick-2013-organizational-behavior-isbn.pdf 
Northouse, P. G. (2013). Leadership: Theory and practice $\left(8^{\text {th }}\right.$ eds.). SAGE Publications. Retrieved from https://studydaddy.com/attachment/146554/Peter_G._Northouse_Leadership _Theory_and_Practiz-lib.org.pdf(Accessed on April 26, 2019).

Özaslan, G. (2018). Principals' conceptions of their current power basis revealed through phenomenography. Journal of Educational Administration, 56(2), 220-235. https://doi.org/ 10.1108/ JEA-10-2016-0120

Semela, T. (2011). Breakneck expansion and quality assurance in Ethiopian higher education: Ideological rationales and economic impediments. Higher Education Policy, 24(3), 399-425. https://doi.org/10.1057/hep.2011.11

Singh, A. (2009). Organizational power in perspective. Leadership and Management in Engineering, 9(4), 165-176. https://doi.org/10.1061/(asce)lm.1943-5630.0000018

Stravakou, P. A., Lozgka, E. C., \& Melissopoulos, S. (2018). The influence of values on educational administration: The School Principals' perspective. International Journal of Education and Research, 6(4), 147-160. Retrieved from https://www.ijern.com/journal/2018/April-2018/12.pdf

Tang, G., Chen, Y., van Knippenberg, D., \& Yu, B. (2020). Antecedents and consequences of empowering leadership: Leader power distance, leader perception of team capability, and team innovation. Journal of Organizational Behavior, 41(6), 551-566. https://doi.org/10.1002/job.2449

Tekleselassie, A. A. (2005). Teachers' career ladder policy in Ethiopia: An opportunity for professional growth or "a stick disguised as a carrot?" International Journal of Educational Development, 25(6), 618-636. https://doi.org/10.1016/j.ijedudev.2004.11.022

Tingle, E., Corrales, A., \& Peters, M. L. (2019). Leadership development programs: Investing in school principals. Educational Studies, 45(1), 1-16. https://doi.org/10.1080/03055698.2017.1382332

Theron, S. (2020). Power and influence in post-secession South Sudan: A leadership perspective on nation-building. African Security Review, 29(1), 1-24. https:// doi.org/10.1080/10246029.2020.1748672

Tran, H. (2020). Revolutionizing school HR strategies and practices to reflect talent centered education leadership. Leadership and Policy in Schools, 1-15. https:// doi.org/10.1080/15700763.2020.1757725

Trinh, T. P. T., Pham, T. V., Cao, H. T., Nguyen, T.-T., Nghiem, T. T., \& Tran, T. (2019). The Profile of Professional Standards for Secondary School Principals in Vietnam. International Journal of Education and Practice, 7(4), 310-323. https://doi.org/10.18488/journal.61.2019.74.310.323

Twalh, A. A. I., Alsolami, H. A., Cheng, K. T. G., \& Islam, G. M. (2016). Power and Influence: CEO Power and the Use of Tactical Influence. Journal of Management and Strategy, 7(2), 46-52. https://doi.org/10.5430/jms.v7n2p46

Van Wyk, A., Van der Westhuizen, P. C., \& Van Vuuren, H. (2014). Resistance to change in schools: Perceptions of principals and teachers in a South African province. Problems and Perspectives in Management, 12(4), 457-656. Retrieved from https://www.researchgate.net

/publication/286661673_Resistance_to_change_in_schools_Perceptions_of_prin cipals_and_teachers_in_a_South_African_province.

Weinstein, J., Raczynski, D., \& Peña, J. (2020). Relational trust and positional power between school principals and teachers in Chile: A study of primary schools. Educational Management Administration \& Leadership, 48(1), 64-81. https://doi.org/10.1177/1741143218792912

Yamane, T. (1967). Elementary sampling theory. New York: Hamper. Retrieved from 
https://www.tandfonline.com/doi/abs/10.1080/01621459.1968.11009297

Yan, R. (2020). The influence of working conditions on principal turnover in K-12 public schools. Educational Administration Quarterly, 56(1), 89-122. https://doi.org/10.1177/0013161×19840391

Yukl, G. (2010). Leadership in organizations (7th $e d$.$) . Upper Saddler River. New Jersey:$ Person. Retrieved from https://www.pearson.com/us/highereducation/product/Yukl-Leadership-in Edition/9780132424318.html

Organizations-7th- 


\section{Appendix}

\section{HARAMAYA UNIVERSITY \\ COLLEGE OF EDUCATION AND BEHAVIORAL SCIENCES \\ DEPARTMENT OF EDUCATIONAL PLANNING AND MANAGEMENT}

Questionnaire to be filled by: Secondary School Teachers, Principals and Supervisors

Dear Respondents, the purpose of this questionnaire is to conduct a research entitled "The Power Sources and Influences of Secondary School Principals in Eastern Ethiopia". The responses you provide will have a paramount importance for the successful accomplishment of this study. Thus, you are kindly requested to give your genuine response. Your responses will be used only for academic purpose and will remain confidential.

\section{Direction:}

Please read each item carefully and record your genuine opinion based on your exposure and knowledge in the area of ethical leadership.

Please do not consult others while responding the items.

Please answer all questions in their order.

It is not necessary to write your name on the questionnaire.

$\rightarrow$ Please return the completed questionnaire to the designated person/supervisor.

Thank you in advance for your kind cooperation!

\section{Part I. General/Personal Information}

1.1. Name of the school that you are working for

1.2. Your current job position

\subsection{Sex: Male $\square \quad$ Female $\square$}

1.4. Age: $\leq 20 \quad \square \quad 21-25 \quad \square \quad 26-30 \quad \square \quad 31-35 \square>36-40 \square \geq 41 \square$

1.5. Total work experience in leadership position years: $\leq 5 \square \quad 6-10 \square \quad 11-15 \square$ 16-20 $\square \geq 21 \square$

1.6. Educational qualification:
Diploma
BA/BSC Degree $\square$
MA/MSC Degree
$\mathrm{PhD}$

1.7. Field of specialization: Educational Leadership and Management DEducational/school Leadership and Management

Others

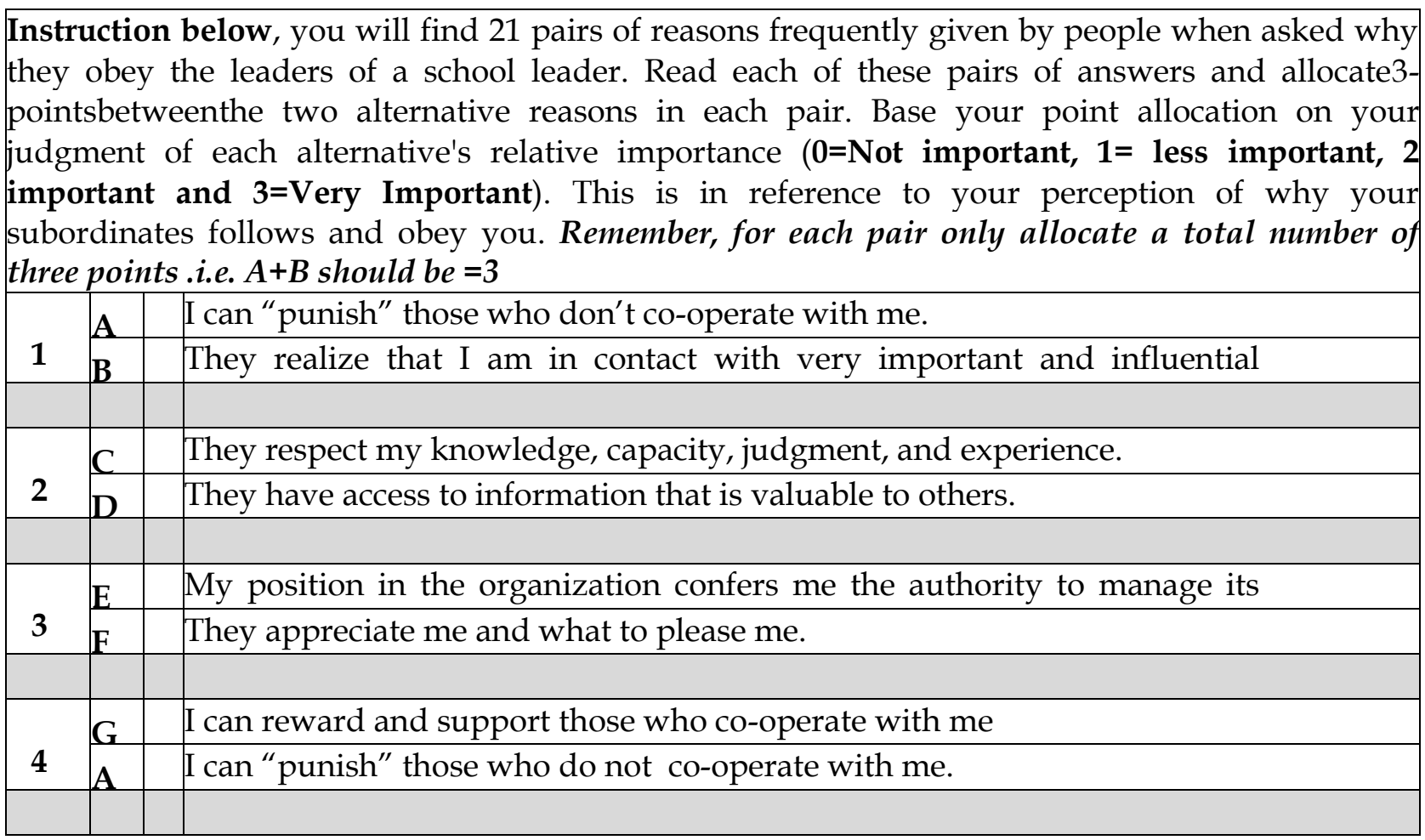




\begin{tabular}{|c|c|c|}
\hline \multirow[b]{2}{*}{5} & B & They realize that I am in contact with very important and influential \\
\hline & C & They respect my knowledge, capacity, judgment and experience. \\
\hline \multirow[b]{2}{*}{6} & D & I have access to information that is valuable to others. \\
\hline & F & My position in the organization confers me the authority to manage its \\
\hline \multirow[b]{2}{*}{7} & F & They appreciate me and what to please me. \\
\hline & G & I can reward and support those who co-operate with me. \\
\hline \multirow[b]{2}{*}{8} & A & I can "punish" those who don't co-operate with me. \\
\hline & C & They respect my knowledge, capacity, judgment and experience. \\
\hline \multirow[b]{2}{*}{9} & B & They realize that I am in contact with very important and influential people. \\
\hline & $\mathrm{D}$ & I have access to information that is valuable to others. \\
\hline \multirow[b]{2}{*}{10} & C & They respect my knowledge, capacity, judgment and experience. \\
\hline & E & My position in the organization confers me the authority to manage its \\
\hline \multirow[b]{2}{*}{11} & D & I have access to information that is valuable to others. \\
\hline & A & I can "punish" those who don't co-operate with me. \\
\hline \multirow[b]{2}{*}{12} & E & My position in the organization confers me the authority to manage its \\
\hline & B & They realize that I am in contact with very important and influential \\
\hline \multirow[b]{2}{*}{13} & $\mathbf{F}$ & They appreciate me and what to please me. \\
\hline & C & They respect my knowledge, capacity, judgment, and experience. \\
\hline \multirow[b]{2}{*}{14} & G & I can reward and support those who co-operate with me. \\
\hline & B & They realize that I am in contact with very important and influential \\
\hline \multirow[b]{2}{*}{15} & A & I can "punish" those who do not co-operate with me. \\
\hline & E & My position in the organization confers me the authority to manage its \\
\hline \multirow[b]{2}{*}{16} & B & They realize that I am in contact with very important and influential people. \\
\hline & F & They appreciate me and what to please me. \\
\hline \multirow[b]{2}{*}{17} & C & They respect my knowledge, capacity, judgment, and experience. \\
\hline & G & I can reward and support those who co-operate with me. \\
\hline \multirow[b]{2}{*}{18} & D & I have access to information that is valuable to others. \\
\hline & F & They appreciate me and what to please me. \\
\hline \multirow[b]{2}{*}{19} & E & My position in the organization confers me the authority to manage its \\
\hline & G & I can reward and support those who co-operate with me. \\
\hline
\end{tabular}




\begin{tabular}{|l|l|l|l|}
\hline 20 & F & They appreciate me and what to please me. \\
\hline & A & I can "punish" those who do not co-operate with me. \\
\hline & & & \\
\hline & G & D & I can reward and support those who co-operate with me. \\
\hline
\end{tabular}

TOTALS:

\begin{tabular}{|l|l|l|l|l|l|l|l|l|}
\hline A & B & C & D & E & F & G & & Sum \\
\hline & & & & & & & $=$ & 63 \\
\hline
\end{tabular}

Key: Please read each statement, and show your position by putting a tick mark $(\square)$ under $1=$ Never, $2=$ Rarely, 3=Sometimes, $4=$ Usually, 5=Always

\begin{tabular}{|c|c|c|c|c|c|c|}
\hline \multirow[t]{2}{*}{ No } & \multirow{2}{*}{$\begin{array}{l}\text { A. Items prepared to assess influences Tactics of principals and supervisors } \\
\text { adopted from Yukl (2010) }\end{array}$} & \multicolumn{5}{|c|}{ Responses } \\
\hline & & 1 & 2 & 3 & 4 & 5 \\
\hline No & $\begin{array}{l}\text { A.Items prepared to assess Proactive Influence Tactics of principals and } \\
\text { supervisors }\end{array}$ & & & & & \\
\hline 1. & use logical arguments and factual evidence to make request feasible & & & & & \\
\hline 2. & explain how the person could benefit from carrying out a requested task. & & & & & \\
\hline 3. & arouse the target person's emotions to gain commitment for a request & & & & & \\
\hline 4. & encourage the target to suggest improvements & & & & & \\
\hline 5. & $\begin{array}{l}\text { offer an incentive and promise to provide an appropriate reward who carry } \\
\text { out a difficult request. }\end{array}$ & & & & & \\
\hline 6. & $\begin{array}{l}\text { provide relevant resources and assistance if the subordinates will carry out a } \\
\text { request }\end{array}$ & & & & & \\
\hline 7. & ask the person to do a favor for you as a friend & & & & & \\
\hline 8. & $\begin{array}{l}\text { use praise before or during an influence by expressing person's ability while } \\
\text { carry out request. }\end{array}$ & & & & & \\
\hline 9. & establish the legitimacy of a request by referring to rules, policies \& contracts & & & & & \\
\hline 10. & use demands and frequent checking that the staff must do what I asked to do & & & & & \\
\hline 11. & seek the aid of others to persuade the subordinates to do something & & & & & \\
\hline
\end{tabular}

Direction: Read the following questions carefully and choose the best answer that describes your influencing tactics and process in your school?

1. What kind of Influencing Tactics you are applying to influences your immediate fellow?
A. Provide praise or offering unconditional help for your subordinate self-promotion.
B. Deception, manipulation and influencing decision makers to promote your interests.
C. Uses logical arguments and factual evidence to make request feasible
D. have switched roles with subordinates and subordinates resist and show unwanted behavior

2. What do you think that your subordinates carry out your requested action?
A. Obtaining a tangible reward or avoiding a punishment.
B. By recognizing compliance is intrinsically desirable \& committed to support their leaders.
C. To gain approval, maintain a relationship, need for acceptance and favor from the leader 